\title{
Pulmonary arterial remodeling induced by a Th2 immune response
}

\author{
Eleen Daley, ${ }^{1}$ Claire Emson, ${ }^{2}$ Christophe Guignabert, ${ }^{3}$ \\ Rene de Waal Malefyt, ${ }^{2}$ Jennifer Louten, ${ }^{2}$ Viswanath P. Kurup, ${ }^{4}$ \\ Cory Hogaboam, ${ }^{5}$ Laimute Taraseviciene-Stewart, ${ }^{6}$ Norbert F. Voelkel, ${ }^{6}$ \\ Marlene Rabinovitch, ${ }^{3}$ Ekkehard Grunig, ${ }^{7}$ and Gabriele Grunig ${ }^{8}$
}

'St. Luke's Roosevelt Hospital, New York, NY 10019

${ }^{2}$ Schering Plough Biopharma, Palo Alto, CA 94304

${ }^{3}$ Department of Pediatrics, Stanford University School of Medicine, Stanford CA 94305

${ }^{4}$ Allergy Immunology Division, Department of Pediatrics, Medical College of Wisconsin, Milwaukee, WI 53295

${ }^{5}$ Department of Pathology, University of Michigan, Ann Arbor, MI 48109

${ }^{6}$ Division of Pulmonary Medicine, Department of Medicine, University of Colorado Health Sciences Center, Denver, C0 80262

7Department of Medicine, Thoraxclinic at the University Hospital Heidelberg, 69117 Heidelberg, Germany

${ }^{8}$ Department of Microbiology, Columbia University, New York, NY 10032

Pulmonary arterial remodeling characterized by increased vascular smooth muscle density is a common lesion seen in pulmonary arterial hypertension (PAH), a deadly condition. Clinical correlation studies have suggested an immune pathogenesis of pulmonary arterial remodeling, but experimental proof has been lacking. We show that immunization and prolonged intermittent challenge via the airways with either of two different soluble antigens induced severe muscularization in small- to medium-sized pulmonary arteries. Depletion of CD4 ${ }^{+} \mathrm{T}$ cells, antigen-specific T helper type 2 (Th2) response, or the pathogenic Th2 cytokine interleukin 13 significantly ameliorated pulmonary arterial muscularization. The severity of pulmonary arterial muscularization was associated with increased numbers of epithelial cells and macrophages that expressed a smooth muscle cell mitogen, resistin-like molecule $\alpha$, but surprisingly, there was no correlation with pulmonary hypertension. Our data are the first to provide experimental proof that the adaptive immune response to a soluble antigen is sufficient to cause severe pulmonary arterial muscularization, and support the clinical observations in pediatric patients and in companion animals that muscularization represents one of several injurious events to the pulmonary artery that may collectively contribute to PAH.

CORRESPONDENCE

Gabriele Grunig:

gg398@columbia.edu

Abbreviations used: Asp Ag, Aspergillus fumigatus antigen; BALF, bronchoalveolar lavage fluid; H\&E, hematoxylin and eosin; i.n., intranasal; PAH, pulmonary arterial hypertension; PCNA, proliferating cell nuclear antigen; RELM, resistin-like molecule; RVSP, right ventricular systolic pressure.
Remodeling of pulmonary arteries is a frequent structural change seen in chronic pulmonary arterial hypertension $(\mathrm{PAH})(1-3)$. Careful histological studies of lung vessels in patients with PAH have shown the presence of different types of lesions (4). Pulmonary arterial muscularization, with an increase in the numbers of vascular smooth muscle cells and smooth muscle cell hypertrophy, is seen frequently (4). Muscularization can be confined to the lamina media, but lesions may extend into the intima and are characterized by an accumulation of smooth

E. Daley and C. Emson contributed equally to this work. Norbert F. Voelkel's present address is Victoria Johnson Center for Obstructive Lung Diseases, Virginia Commonwealth University, Richmond, VA 23284.

The online version of this article contains supplemental material. muscle cells between the endothelial cell layer and the elastic lamina that borders the lamina media (5). Chronic exposure to hypoxia is the best studied cause of pulmonary arterial muscularization, as it is thought to provide the structural basis for hypoxic vasoconstriction and pulmonary hypertension (4).

$\mathrm{PAH}$ as a primary disease is rare (idiopathic $\mathrm{PAH}$ ); however, PAH as a secondary condition is much more common $(6,7)$. Pulmonary arterial remodeling, together with other factors such as vasoconstriction, are thought to cause progressive $\mathrm{PAH}$ and right ventricle dysfunction. Collectively, the structural and functional changes in the heart and lung vasculature reduce both life quality and expectancy for $\mathrm{PAH}$ patients $(6,7)$. There is strong circumstantial evidence for an immune pathogenesis 
of PAH. PAH is associated with rheumatoid arthritis, systemic lupus erythematosus, collagen diseases (e.g., scleroderma and mixed connective tissue disease), hypothyroidism, hypersensitivity pneumonitis, and infection with HIV (8-10). Barst et al. and Morse et al. detected an association of MHC class II alleles with PAH (11-13). Despite this, there is no evidence for the familial form of PAH being associated with specific MHC class II alleles, indicating that the familial form of PAH may have no immunogenetic origin (14). Therefore, there is currently no direct evidence for the pathogenic role of the immune response for pulmonary arterial remodeling and $\mathrm{PAH}$. The present study describes new models of antigen-induced pulmonary arterial muscularization that demonstrate a mechanistic link between an antigendriven Th2 immune response and severe pulmonary arterial remodeling.

A

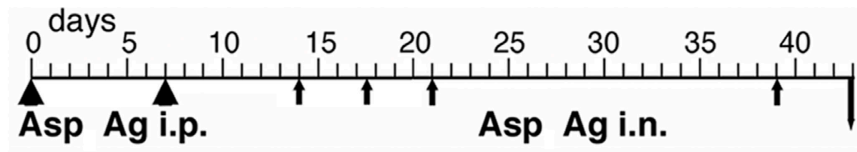

PBS

Asp $\mathbf{A g}_{\text {s }}$

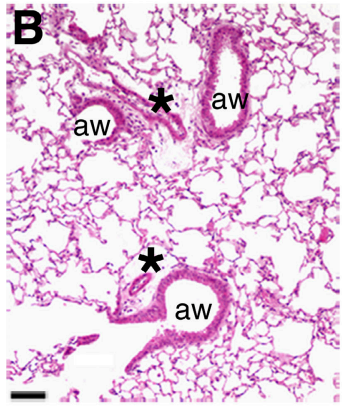

E

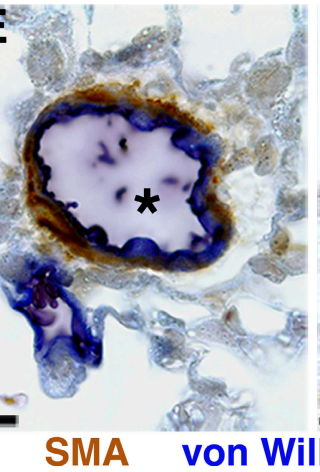

$\mathbf{F}$

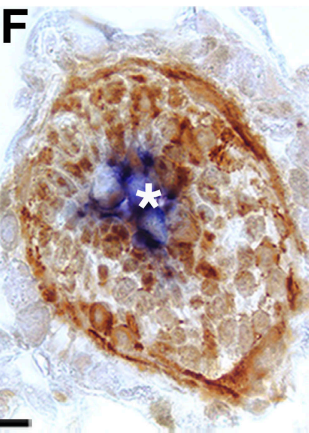

-

H Arterial Remodeling I

Ki67
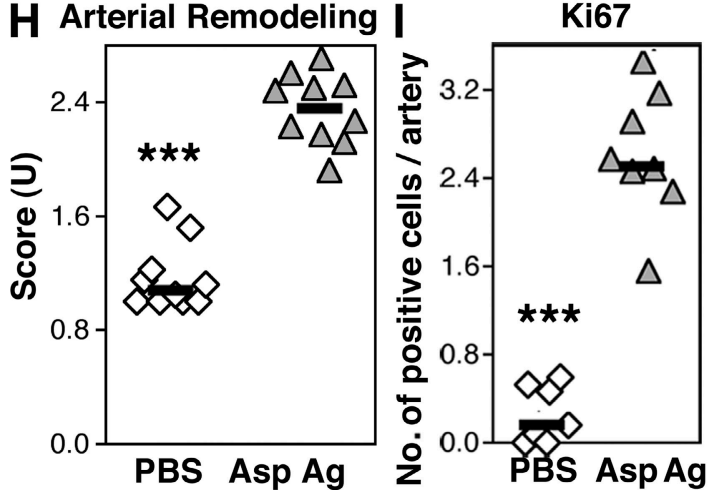

SMA Ki67
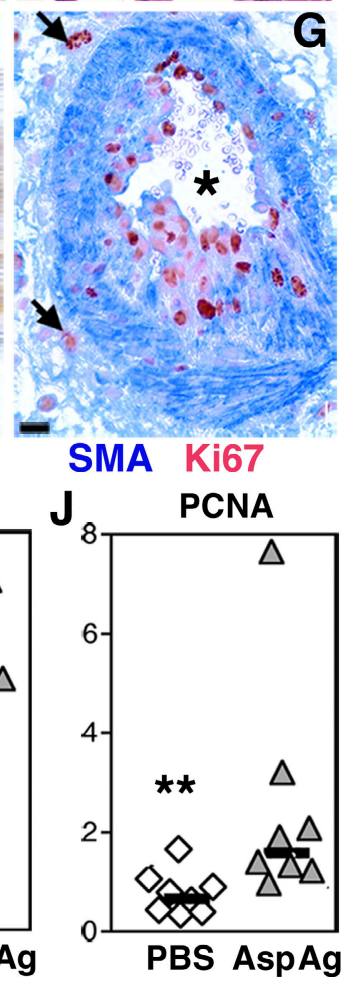

Figure 1. Severe pulmonary arterial remodeling in Asp Ag-exposed mice. (A) Schematic representation of the protocol for priming and challenge (i.p., arrowheads; i.n., arrows) with Asp Ag. (B-G) Lung micrographs from mice exposed to PBS (B and E) or Asp Ag (C, D, F, and G) show H\&E staining (B-D) or immunohistochemistry of smooth muscle actin (SMA, brown) and von Willebrand factor (blue; E and F), or SMA (blue) and Ki67 (red; G). Arteries (*), airways (aw), and inflammatory cells (arrows) are indicated. Bars: (B and C) $75 \mu \mathrm{m}$; (D and G) $12.5 \mu \mathrm{m}$; (E and F) $7.5 \mu \mathrm{m}$. Individual data, medians (horizontal lines), and differences between PBS- and Asp Ag-exposed mice (***, P<0.001; and ${ }^{* *}, \mathrm{P}<0.01$ according to the Wilcoxon $U$ test) are shown for arterial remodeling scores $(\mathrm{H})$ and numbers of Ki67- (I) or PCNA-expressing (J) cells in pulmonary arteries. Data were pooled from two independent experiments. 


\section{RESULTS}

Severe pulmonary arterial remodeling develops in immunized mice given prolonged intermittent exposure to intranasal (i.n.) Aspergillus fumigatus antigen (Asp Ag)

We found that primed mice given i.n. Asp Ag intermittently for a prolonged period of time (Fig. 1 A) developed severe thickening of the walls of small- to medium-sized pulmonary arteries (Fig. 1, B-D and H). Cells multilayered within the thickened wall of the remodeled pulmonary arteries expressed smooth muscle actin, whereas von Willebrand factor-expressing endothelial cells remained in a single-cell layer (Fig. 1, E and F). The number of cells within the remodeled arterial walls that were positive for the nuclear proliferation markers Ki67 (Fig. 1, $\mathrm{G}$ and $\mathrm{I}$ ) or proliferating cell nuclear antigen (PCNA; Fig. $1 \mathrm{~J}$; and Fig. S1, available at http://www.jem.org/cgi/content/ full/jem.20071008/DC1) was increased in antigen-primed, challenged mice compared with saline-exposed controls.

Severe pulmonary arterial remodeling develops in immunized mice given prolonged intermittent exposure to aerosolized OVA

Exposure to soluble Asp Ag, known to have immunostimulatory and cell-toxic activities, could have caused pulmonary arterial muscularization by an adaptive immune response, stimulation of innate immune cells, or toxicity to lung-resident cells $(15,16)$. To distinguish between these possibilities, the response to immunization and prolonged intermittent challenge to a largely harmless antigen (OVA) was analyzed (Fig. 2 A). The OVA-exposed mice consistently showed severe thickening of the arterial walls, with an increase in smooth muscle actin-expressing cells, increase in cells expressing nuclear Ki67, and significant changes in the cellular organization (Fig. 2; and Figs. S1 and S2, available at http://www .jem.org/cgi/content/full/jem.20071008/DC1). Collectively, the data showed that severe pulmonary arterial muscularization was the result of prolonged intermittent antigen challenge in primed mice. Muscularization was detected in nearly one half of the microscopic view fields analyzed from Asp Ag-primed and-challenged mice and in approximately one third of the view fields analyzed from OVA-primed and -challenged mice (Table I). The complete study presented in this manuscript used 188 mice; $>4,500$ microscopic view fields (Table S1, available at http://www.jem.org/cgi/content/full/ jem.20071008/DC1) and >38,000 smooth muscle cells were analyzed (Table II).

Severe, antigen-induced pulmonary arterial remodeling requires the presence of $C D 4^{+} \mathrm{T}$ cells

To determine the mechanism by which prolonged intermittent exposure to antigen causes severe pulmonary arterial muscularization, the effect of $\mathrm{CD}^{+}{ }^{+} \mathrm{T}$ cell depletion was studied in Asp $\mathrm{Ag}$-primed and -challenged mice (Fig. 3; and Fig. S3, available
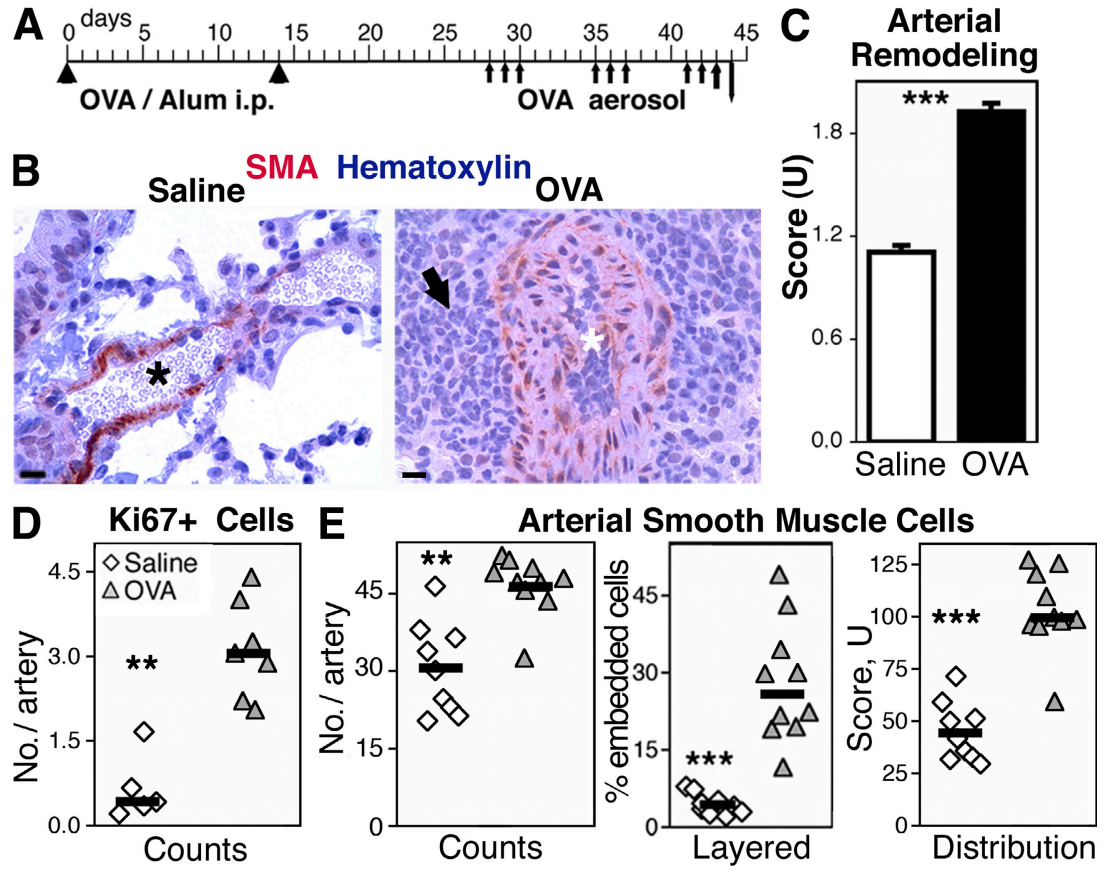

Figure 2. Severe pulmonary arterial remodeling in OVA-exposed mice. (A) Schematic representation of the protocol for priming and challenge (i.p., arrowheads; i.n., arrows) with OVA. (B) Lung micrographs show immunohistochemistry of smooth muscle actin (SMA, red) with hematoxylin (blue) counterstain from saline- or OVA-exposed mice. Arteries $\left({ }^{*}\right.$ ) and inflammatory cells (arrow) are indicated. Bars: $12.5 \mu \mathrm{m}$. (C) Bar graphs show means and SEM of arterial remodeling scores in mice exposed to saline or OVA (***, $\mathrm{P}<0.0001$ according to the Wilcoxon $\mathrm{U}$ test; $n=14-15$ mice). Individual data, medians (horizontal lines), and differences between PBS- and OVA-exposed mice ${ }^{* *}, \mathrm{P}<0.01$; and ${ }^{* *}, \mathrm{P}<0.001$ according to the Wilcoxon $\mathrm{U}$ test) are shown for (D) numbers of Ki67+ cells, and (E) counts, percent layered, and distribution scores of smooth muscle cells in pulmonary arteries. The data were pooled from two independent experiments. 
Table I. Analysis of primed and antigen-challenged wildtype mice and naive mice given recombinant IL-13

\begin{tabular}{|c|c|c|c|}
\hline Challenge & Mice & View fields & Score of 3 \\
\hline Asp $A^{a}{ }^{a}$ & $\begin{array}{c}38 \\
\text { (primed) }\end{array}$ & $\begin{array}{c}1,009 \\
\text { (27 per mouse) }\end{array}$ & $\begin{array}{c}459 \\
(45 \%)\end{array}$ \\
\hline $\mathrm{OVA}^{\mathrm{a}}$ & $\begin{array}{c}22 \\
\text { (primed) }\end{array}$ & $\begin{array}{c}635 \\
\text { (29 per mouse) }\end{array}$ & $\begin{array}{c}198 \\
(31 \%)\end{array}$ \\
\hline IL-13b & $\begin{array}{c}10 \\
\text { (naive) }\end{array}$ & $\begin{array}{c}197 \\
\text { (20 per mouse) }\end{array}$ & 0 \\
\hline
\end{tabular}

The number of mice examined, the number of microscopic view fields scored (total number and mean number per mouse), and the number and percentage of view fields given the score of 3 for severe degree of pulmonary arterial muscularization are shown.

aPrimed wild-type mice were challenged with antigen and given nothing or control antibody.

${ }^{b}$ Naive wild-type mice were challenged with recombinant IL-13.

at http://www.jem.org/cgi/content/full/jem.20071008/DC1). Mice depleted of $\mathrm{CD}^{+} \mathrm{T}$ cells did not develop severe pulmonary arterial remodeling, in contrast to mice given control antibody (Fig. 3). Administration of control antibody to antigen-primed and-challenged mice had no effect on the development of pulmonary arterial remodeling (Fig. S4). Depletion of CD4 T cells also caused a highly significant decrease in the degree of inflammation elicited in the lungs by Asp Ag exposure (Fig. S3).
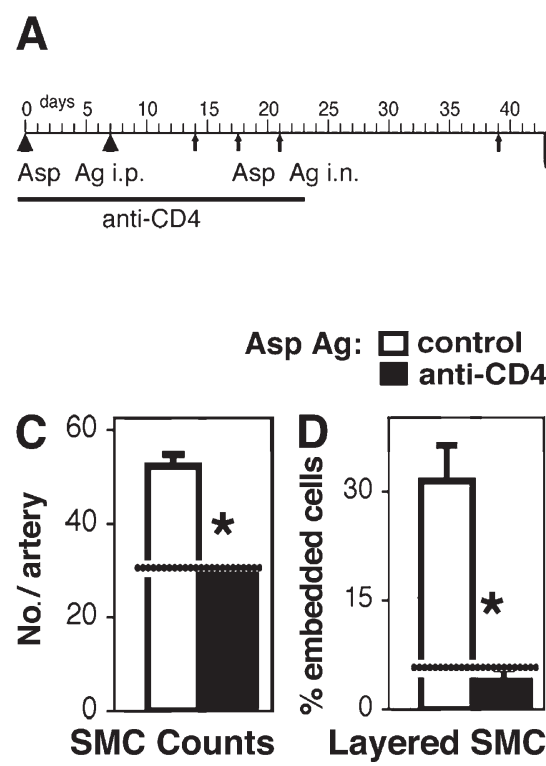

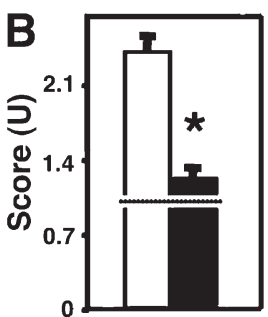

Arterial Remodeling

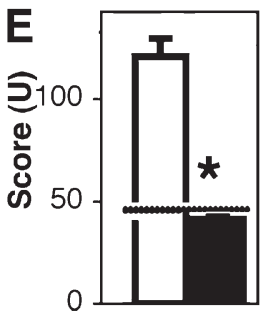

SMC Distribution
Figure 3. Severe pulmonary arterial remodeling is dependent on the presence of $\mathrm{CD}^{+} \mathrm{T}$ cells. (A) Schematic representation of the protocol for $\mathrm{CD}^{-}{ }^{-} \mathrm{T}$ cell depletion (i.p., arrowheads; i.n., arrows). Bar graphs show means and SEM of (B) scores for arterial remodeling, (C) counts, (D) percent layered, and (E) distribution score of smooth muscle cells (SMC) in pulmonary arteries from mice primed and challenged with Asp Ag and given control or anti-CD4 antibody. Differences between groups $\left({ }^{*}, \mathrm{P}<\right.$ 0.05 according to the Wilcoxon $U$ test; $n=4$ mice) and mean scores determined in PBS-exposed mice (horizontal lines) are indicated.
Table II. Extent of the analysis of pulmonary arterial muscularization by numerical evaluation of pulmonary artery smooth muscle cells

\begin{tabular}{lccc}
\hline Model & Mice & Arteries & Smooth muscle cells \\
\hline Asp Ag $^{a}$ & $64^{b}$ & $767^{c}$ & 30,571 \\
OVA $^{a}$ & 19 & $192^{\mathrm{d}}$ & 7,532 \\
\hline
\end{tabular}

Numbers of mice, pulmonary arteries, and smooth muscle cells that were analyzed are shown.

aGroups of mice (wild type or $\mathrm{KO}$ ) were given saline, or primed and challenged with antigen and given nothing, control, or neutralizing antibody.

'The sections of 4 out of the 64 mice were analyzed on two separate, independent occasions.

cNumber of arteries examined in 68 lung sections.

dNumber of arteries examined in 19 lung sections.

The Th2 response determines the severity of pulmonary arterial remodeling in immunized and antigenchallenged mice

In keeping with the known elicitation of Th2 immune responses in wild-type mice immunized with Asp Ag or OVA adsorbed to Alum $(17,18)$, we found that the severity of pulmonary arterial remodeling was correlated with the levels of Th2-induced serum Igs (IgE and IgG1) and bronchoalveolar lavage fluid (BALF) cytokines (IL-5 and IL-4). This was observed in immunized mice exposed to either Asp Ag (Fig. 4 A; and Fig. S5 A, available at http://www.jem.org/cgi/content/ full/jem.20071008/DC1) or OVA (Fig. 4 B; and Fig. S5, C and D). No such correlation was found with Th1-dependent IgG2a (Fig. S5 B) or IFN- $\boldsymbol{\gamma}$ (Fig. S5 E).

To test the hypothesis that the Th2 response to prolonged intermittent antigen exposure causes pulmonary arterial muscularization, IL-4-deficient (IL-4KO) mice, known to be incapable of developing a polarized Th2 response to immunization and challenge with Asp Ag (17), were examined. Antigenprimed and -challenged IL-4KO mice developed significantly less severe pulmonary arterial remodeling relative to wildtype mice (Fig. 5).

The severity of pulmonary arterial remodeling is dependent on indirect effects of IL-13

The role of endogenous IL-13 was examined using specific inhibitors (19), with the goal of identifying a mediator through which the Th2 response in the lungs induces arterial remodeling, because IL-13 has been shown to be capable of mediating several different Th2 response-induced lung disease phenotypes $(18,20,21)$. Immunized mice transiently given an IL-13 inhibitor during the first part of the exposure to i.n. antigen developed significantly less severe pulmonary arterial remodeling compared with mice given control Ig (Fig. 6). These data demonstrated that endogenous IL-13 was necessary to induce severe pulmonary arterial remodeling. To test if IL-13 would be sufficient, naive mice were given i.n. recombinant IL-13 intermittently over several weeks (Fig. S6 A, available at http://www.jem.org/cgi/content/full/jem .20071008/DC1). These mice did not develop severe arterial remodeling (Table I; and Fig. S6 B) despite the presence of 

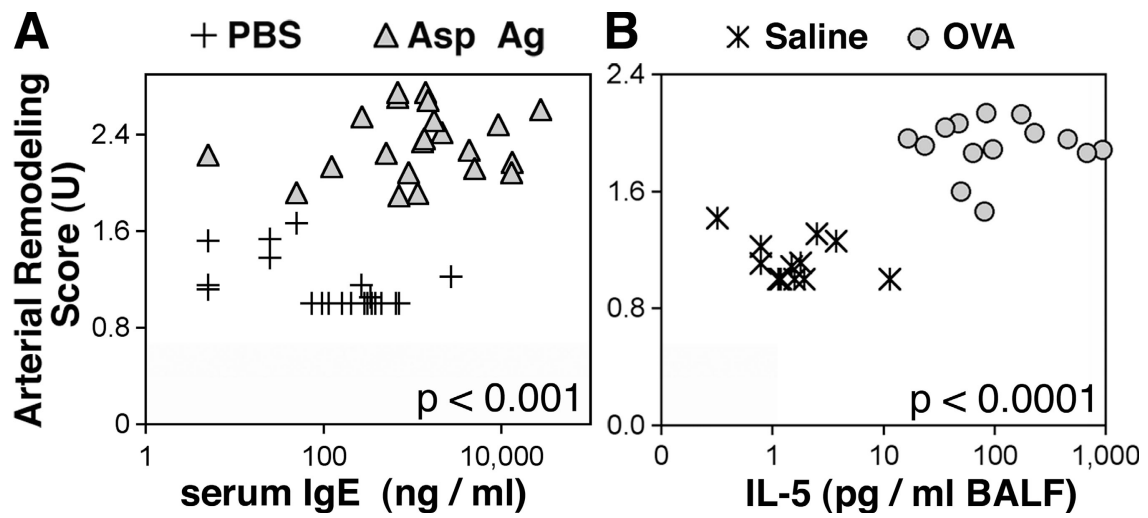

Figure 4. Severe pulmonary arterial remodeling is associated with the development of a Th2 response in Asp Ag- or OVA-exposed mice. Individual data points are shown of arterial remodeling scores plotted against (A) serum lgE levels in mice given PBS or Asp Ag priming and challenge, or (B) BALF IL-5 levels in mice given saline or OVA priming and challenge. The data were analyzed by Spearman's rank correlation test.

significant interstitial inflammation (Fig. S6 C). The effects of endogenous IL-13 in immunized and antigen-challenged mice might be indirect by regulating $\mathrm{Th} 2$ responsiveness, as suggested by the positive correlation of pulmonary arterial muscularization with IL-5-expressing T cells, the negative correlation with IFN- $\boldsymbol{\gamma}$-producing $\mathrm{T}$ cells, and no correlation with the numbers of CD4 T cells in the lung-draining lymph nodes (Fig. S7).

\section{Antigen-induced, Th2-dependent severe pulmonary arterial muscularization and hypoxia might share common mediators}

The similarity of the type of arterial remodeling induced by an antigen-driven Th2 immune response (Figs. 1 and 2) and by exposure to chronic hypoxia (22) raised the question of whether common mediators might be involved. Resistin-like molecule (RELM) $\alpha$ expression in the lungs is highly up-regulated by Th2- and IL-13-mediated inflammation $(23,24)$, as well as hypoxia (25). Probing lung sections for RELM $\alpha$ expression, we found that significantly increased numbers of $\mathrm{RELM} \alpha^{+}$cells bordered the remodeled pulmonary arteries in immunized and antigen-challenged mice compared with unimmunized controls (Fig. 7). As expected, RELM $\alpha^{+}$cells were epithelial cells and macrophages (Fig. S8, available at http://www.jem.org/cgi/content/full/jem.20071008/DC1) $(23,24)$. In some pulmonary arteries, the surrounding connective tissue was also weakly positive (Fig. 7 A). Consistent with the role of endogenous IL-4 in antigen-induced pulmonary arterial remodeling (Fig. 5), counts of RELM $\alpha^{+}$cells were significantly lower in antigen-exposed IL-4KO mice when compared with wild types (Fig. 7 B).

\section{Antigen-induced, Th2-dependent severe pulmonary arterial muscularization and right ventricular systolic pressure (RVSP)}

Prolonged exposure to hypoxia leads to increased pulmonary artery pressure that is associated with the muscularization of the pulmonary artery and a decrease in vascularization (26). Because we observed dramatic pulmonary arterial muscularization, the hypothesis was tested that this would cause increased pulmonary arterial pressure. Immunized mice were randomized into two groups: one was exposed to saline and
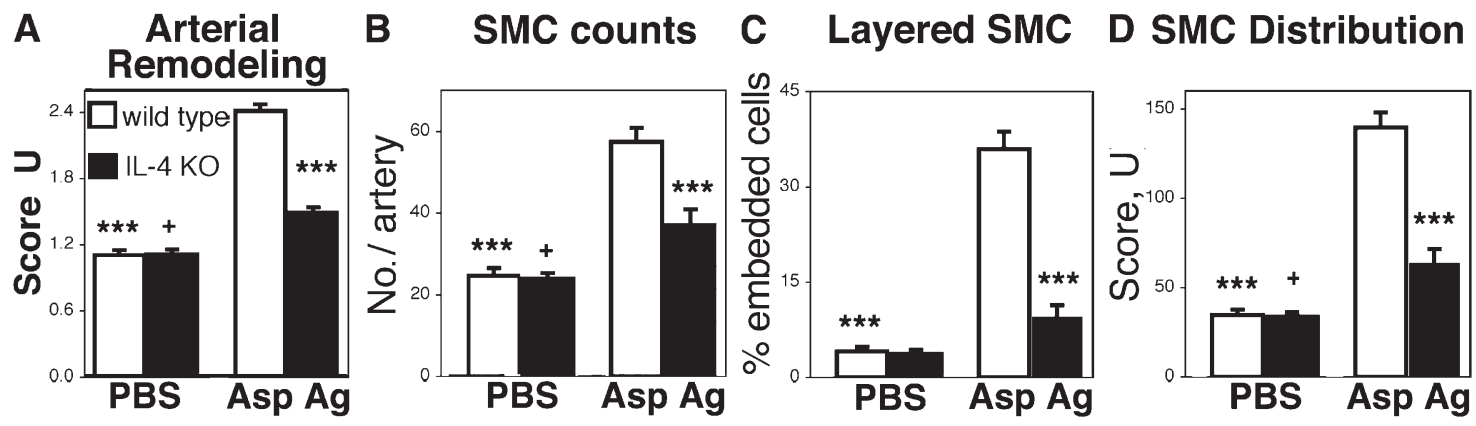

Figure 5. The IL-4-dependent Th2 response induces severe pulmonary arterial remodeling. Bar graphs show means and SEM of (A) arterial remodeling scores, (B) pulmonary artery smooth muscle cell (SMC) counts, (C) percent layered SMC, and (D) SMC distribution scores from wild-type mice or IL-4KO mice given PBS or Asp Ag priming and challenge. Groups that were significantly different from antigen-primed and -challenged wild-type mice $\left({ }^{* * *}, \mathrm{P}<0.001\right)$ or from antigen-primed and -challenged IL-4KO mice $(+, \mathrm{P}<0.05)$ are indicated (Bonferroni test; $n=7-10$ mice). The data were pooled from two independent experiments. 
A
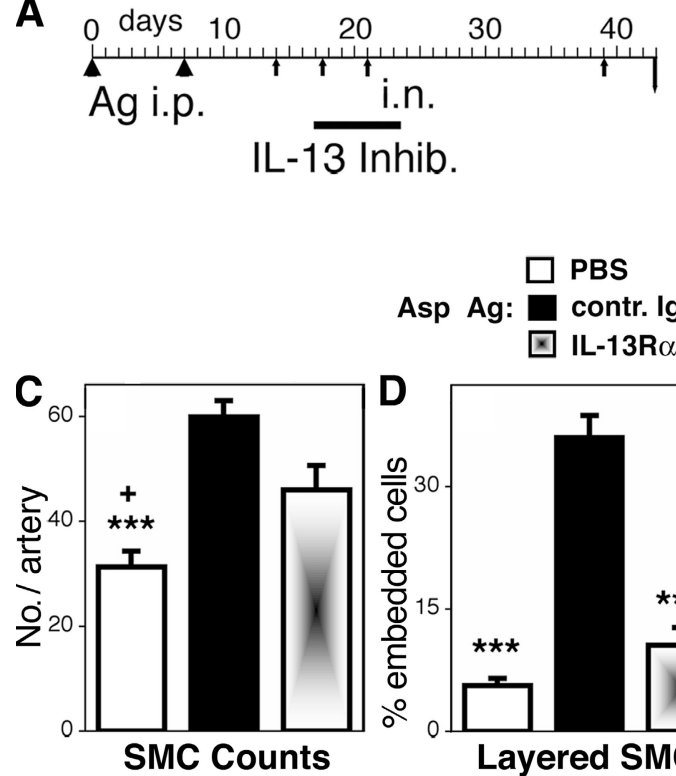

Asp Ag: $\square$ contr. Ig 回-13R $\alpha 2 F c$

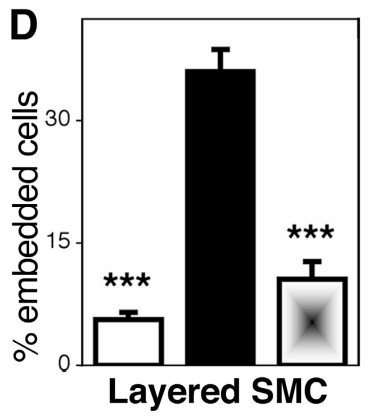

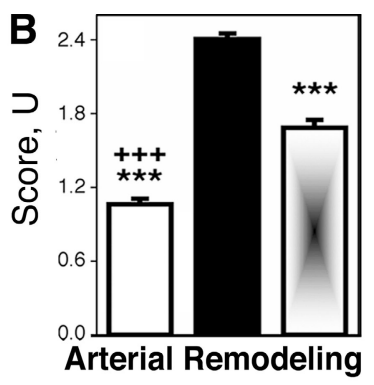

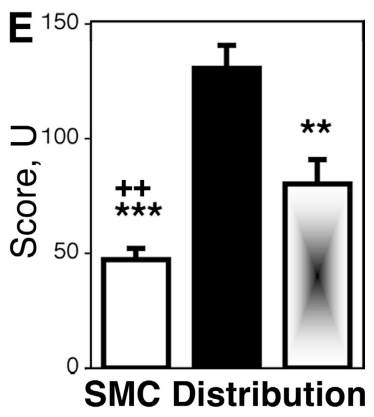

Figure 6. Endogenous IL-13 is critical for pulmonary arterial remodeling. (A) Schematic representation of the protocol for transient IL-13 blockade with IL-13R $\alpha 2$ mouse Ig constant region (IL-13R $\alpha 2-F c)$ in mice primed and challenged with Asp Ag. Bar graphs show means and SEM of (B) arterial remodeling scores, (C) pulmonary artery smooth muscle cell (SMC) counts, (D) percent layered SMC, and (E) SMC distribution scores in mice given PBS or Asp Ag priming and challenge and mouse Ig or IL-13R $\alpha 2-F c$. Groups that differ from antigen-exposed mice given Ig $\left(^{* *}, P<0.01 ; *{ }^{* *}, P<\right.$ $0.001)$ or IL-13R $\alpha 2-F c(+, P<0.05 ;++, P<0.01 ;+++, P<0.001)$ are indicated (Bonferroni test; $n=9-11$ mice). The data are pooled from two independent experiments.

the other was exposed to OVA aerosols (Fig. 8). RVSP was determined using a technique optimized to minimize the effects of the measurement itself on heart and lung function. There was no correlation between RVSP and pulmonary arterial remodeling (Fig. 8), although the OVA-exposed mice showed the expected $\mathrm{T}$ cell responses in the lung draining lymph node, as well as the expected histological lesions in the lungs (Fig. 8; Table S2; and Fig. S9, available at http://www .jem.org/cgi/content/full/jem.20071008/DC1). Stimulation with hypoxia for a few minutes led to significantly increased
RVSP in the OVA-challenged animals that had developed severe pulmonary arterial remodeling (Fig. 8). The salineexposed, immunized mice were optimal to specifically probe the role of muscularization for the development of increased RVSPs because these mice did not show signs of arterial remodeling or inflammation (Fig. 8; Table S2; and Fig. S9). The failure to detect signs of right heart hypertrophy (Table S2) was an independent confirmation of the lack of significant pulmonary hypertension at normoxia in the group of OVAexposed mice that showed pulmonary arterial muscularization.
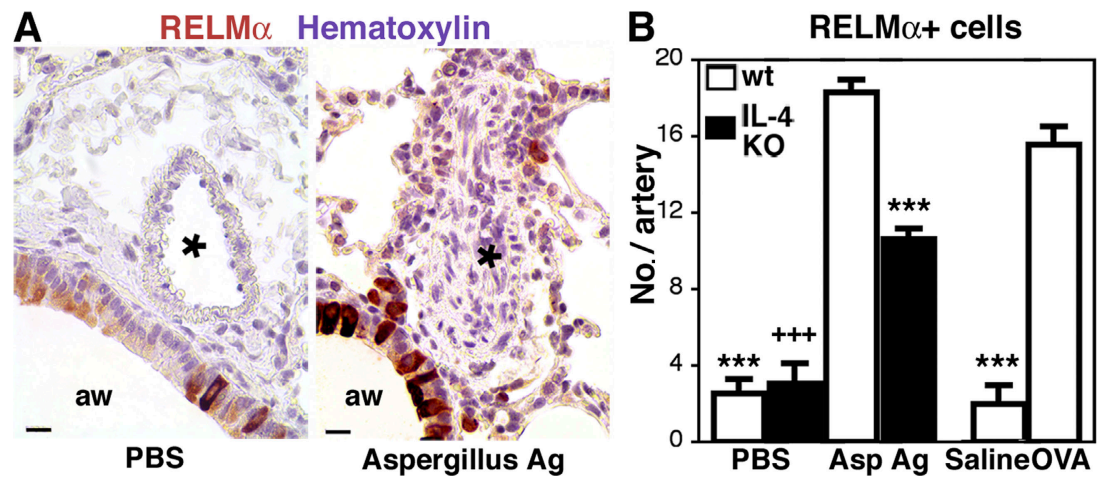

Figure 7. Severely remodeled pulmonary arteries are surrounded by RELM $\alpha$-expressing cells. (A) Lung micrographs show immunohistochemistry of goat anti-RELM $\alpha$ (red) counterstained with hematoxylin (blue) from mice given PBS or Asp Ag priming and challenge. Arteries (*) and airways (aw) are indicated. Bars, $12.5 \mu \mathrm{m}$. (B) Bar graphs show means and SEM of counts of RELM $\alpha^{+}$cells in wild-type or IL-4KO mice exposed to PBS, Asp Ag, saline, or OVA. Groups different from antigen-primed and challenged wild-type $\left.{ }^{* * *}\right)$ or IL-4KO $(+++)$ mice are indicated $(P<0.001$ according to the Bonferroni test; $n=5-10$ mice). Data were pooled from two independent experiments for each antigen and mouse strain. 


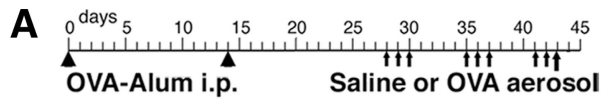

day 44: Hemodynamics \& Histology
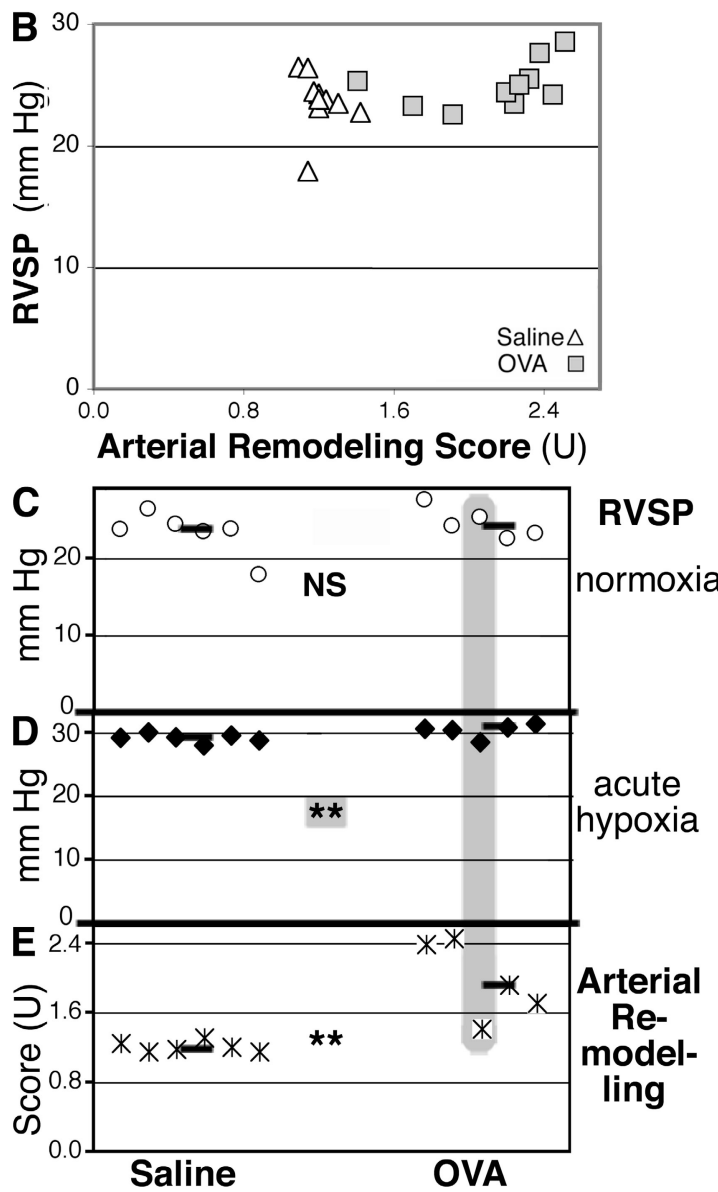

Figure 8. Relationship between RVSP and pulmonary arterial remodeling scores. (A) Mice were immunized and exposed to saline or OVA aerosol as shown (i.p., arrowheads; i.n., arrows). (B) Data points show RVSP plotted against arterial remodeling scores in individual mice. The analysis by Spearman's rank correlation test was not significant. Symbols show RVSP in response to (C) normoxia, (D) acute hypoxia (10 min of breathing $10 \% \mathrm{O}_{2}$ ), and (E) corresponding arterial remodeling scores. Data from individual mice are aligned vertically; horizontal bars indicate medians. Statistical analysis was performed with the two-tailed, independent Wilcoxon $U$ test. ${ }^{*}, \mathrm{P}<0.01$ for the comparison of groups excluding the outlier in the OVA group that did not show severe pulmonary arterial remodeling (outlier data are highlighted in gray; $D) ;{ }^{*}, P<0.01$ for the comparison of groups including all data $(E)$.

\section{DISCUSSION}

The increased incidence of PAH in autoimmune diseases (8-10), chronic obstructive pulmonary disease $(27,28)$, hypersensitivity pneumonitis (29), and infectious disease $(30,31)$ has suggested that chronic inflammation provides signals that cause pulmonary arterial remodeling. Inflammation is also associated with pulmonary arterial muscularization in experimental animals, e.g., rats exposed to monocrotaline $(32,33)$, transgenic mice that overexpress S100A4/Mts1 (a tumorassociated protein) in the lungs (34), animals exposed to chronic hypoxia (22), and mice that lack vasoactive intestinal peptide (35). An immune etiology of PAH has been suggested by elegant studies demonstrating the association of PAH with autoantibodies to nuclear or vascular antigens, and with polymorphic alleles of the human MHC class II complex, such as HLADR 3 and HLA-DQ7 (11-13, 31, 36-39). The increased numbers of T cells, B cells, mast cells, macrophages, and dendritic cells, as well as the detection of inflammatory cytokines and chemokines in the lungs of patients with $\mathrm{PAH}$, have further suggested a pathogenic role for immune or inflammatory processes (5, 40-45). Collectively, these studies give correlative evidence for a role of inflammation and the immune response in pulmonary arterial muscularization.

The study presented in this paper is the first to provide direct experimental proof that the immune response can induce severe pulmonary arterial remodeling. Our data clearly show that intermittent challenge over a period of several weeks with two different antigens induced pulmonary arterial muscularization. Our studies demonstrate that $\mathrm{CD}^{+}{ }^{+} \mathrm{T}$ cells, the IL-4induced Th2 response, and endogenous IL-13 are requisite components of the mechanism that causes antigen-induced severe pulmonary arterial muscularization. Curtis et al. (46) described pulmonary arteriopathy with myointimal thickening of the arterial walls in immunized mice exposed to inhaled, particulate (sheep red blood cell) antigens. Immunized mice acutely challenged with soluble antigen develop increased vascular smooth muscle actin-positive cells surrounding pulmonary blood vessels (47), and an increased vasoconstrictor response in isolated pulmonary arteries (48). Asthmatic patients and BALB/ c mice challenged with soluble antigen demonstrate increased vascularization of the airway mucosa (49). However, severe arterial muscularization is not elicited $(18,47-51)$. Our study suggests that the prolonged and intermittent antigen challenge schedule provides the Th2 immune response regulated signals for cell proliferation, or differentiation of smooth muscle actin-positive cells, and rearrangement of the cellular organization resulting in a severely remodeled arterial wall.

We show that IL-13, and likely IL-4, act indirectly by eliciting additional effectors (soluble mediators or cells) of the type 2 immune response. Our results are in keeping with data demonstrating mild vascular remodeling in response to recombinant IL-13 in a particularly susceptible mouse strain (52), and with the failure to detect severe arterial remodeling in mice that carry a transgene overexpressing IL-13 or IL-4 in airway epithelial cells (53-55).

The arterial remodeling described in our studies and that observed in animals chronically exposed to hypoxia is highly similar in both morphology (the thickening and reorganization of the smooth muscle cell constituents of the arterial wall, and the increase in proliferation marker-positive cells; references $22,56)$ and in the increased expression of RELM $\alpha$. Mouse RELM $\alpha$ is also named hypoxia-induced mitogenic factor (25), because it and its human homologue (RELMß) (57) are mitogenic for vascular smooth muscle cells. Human RELM $\beta$ is expressed in the human lung and is elevated in hypoxiaexposed cultured lung cells (57). 
In keeping with previous studies in the mouse demonstrating that pulmonary hypertension can be measured in the absence of significant pulmonary arterial muscularization (58-61), our studies clearly show that pulmonary arterial muscularization, even when present at a advanced degree and affecting a significant area of the lungs, does not necessarily cause pulmonary hypertension. Our data are supported by clinical observations in pediatric patients with a congenital heart defect associated with remodeling of the pulmonary arteries. In some of these patients, the pulmonary arterial pressure normalizes the day after surgical heart repair despite the presence of pulmonary arterial muscularization $(62,63)$. Pulmonary arterial muscularization and hypertension can also be caused by helminth parasites such as Schistosoma species (64-66) or Dirofilaria species $(67,68)$. D. immitis infection of cats induces significant pulmonary arterial muscularization that is not necessarily accompanied by pulmonary hypertension (69), and similar conclusions have been suggested in D. immitis-infected dogs (70).

Our data show for the first time that the Th2 immune response to soluble antigen is sufficient to cause severe pulmonary arterial muscularization. Our study suggests that the activation of shared mediators, such as RELM $\alpha(23-25,57)$, might produce similar morphological alterations in the pulmonary arteries in response to either Th2-mediated inflammation or chronic hypoxia. These data might have implications for the identification of novel diagnostic and therapeutic targets for pulmonary arterial remodeling.

\section{MATERIALS AND METHODS}

Mice. Wild-type C57BL/6 and IL-4 KO mice (71) on the C57BL/6 background were purchased from the Jackson Laboratory. The mice were housed in specific pathogen-free conditions at St. Luke's Roosevelt Hospital or Schering-Plough Biopharma. All experiments were performed according to guidelines outlined by the United States Department of Agriculture and the American Association of Laboratory Animal Care under the supervision of the Institutional Animal Care and Use Committee at St. Luke's Roosevelt Hospital or Schering-Plough Biopharma.

Model for pulmonary arterial muscularization in Asp Ag-primed and -challenged mice. The mice were housed at St. Luke's Roosevelt Hospital for all studies that required Asp Ag priming and exposure, and the experiments were performed under G. Grunig's supervision. Groups of mice were either given PBS or primed and challenged i.n. with crude Asp Ag free of viable fungus $(50,72)$. Priming consisted of two weekly i.p. injections of $91 \mu \mathrm{g}$ Asp Ag in a 100- $\mu$ l volume of PBS (Fig. 1 A). Challenges were given i.n. to lightly anaesthetized mice with $100 \mu \mathrm{g}$ of antigen in a $50-\mu$ l volume of PBS. Control mice were not primed and received PBS i.p. and i.n. The mice were killed $4 \mathrm{~d}$ after the final i.n. exposure.

Model for pulmonary arterial muscularization in OVA-primed and -challenged mice. For this part of the study, the experiments were performed at Schering Plough Biopharma under R. de Waal Malefyt's supervision. OVA (grade V; Sigma-Aldrich) was diluted to $1 \mathrm{mg} / \mathrm{ml}$ in $0.15 \mathrm{M}$ of sterile saline (Sigma-Aldrich), complexed with Alum (Imject Alum; Thermo Fisher Scientific), and injected i.p. (final dose $=50 \mu \mathrm{g}$ OVA and $2 \mathrm{mg}$ Alum), as shown in Fig. 2 A. Challenges with aerosolized OVA were given for $45 \mathrm{~min}$ at a concentration of 10 or $25 \mathrm{mg} / \mathrm{ml}$ (day 43 only). Mice were killed on day 44 .

Depletion of CD4 T cells. Groups of wild-type mice were primed and challenged with Asp Ag (Fig. $3 \mathrm{~A}$ ) and given $0.6 \mathrm{mg}$ per mouse of a depleting
$\mathrm{mAb}$ to $\mathrm{CD} 4$ (clone GK1.5) or control mAb i.p. $2 \mathrm{~d}$ before the first priming dose of Asp Ag. The antibody injections were repeated at 5-7-d intervals. The schedule of administration of the anti-CD4 antibody was based on the published efficacy of this antibody for depletion of naive $\mathrm{CD} 4^{+} \mathrm{T}$ cells (73). The mice were rested, given a final i.n. challenge, and killed $4 \mathrm{~d}$ later (Fig. $3 \mathrm{~A}$ ). Control mice were not immunized, and given PBS and no antibody.

At the end of the experiment, single-cell suspensions were prepared from one lung lobe and the spleens. The cells were examined for numbers of $\mathrm{CD} 4^{+}$ $\mathrm{T}$ cells and for the ratio of $\mathrm{CD} 4^{+} / \mathrm{CD}^{+} \mathrm{T}$ cells using flow cytometry and an anti-CD4 antibody labeled with peridium chlorophyll protein (PerCp; BD Biosciences) and an anti-CD8 antibody labeled with FITC (eBioscience). The data were acquired on a flow cytometer (FACSCalibur) and analyzed with CellQuest software (both from BD Biosciences).

Determination of the role of IL-4 and the Th2 response. Groups of IL-4-deficient (IL-4KO) and wild-type mice were given PBS or were immunized and challenged i.n. with Asp Ag using the protocol outlined in Fig. 1 A.

IL-13 neutralization. Groups of wild-type mice were given PBS or primed and challenged with Asp Ag (Fig. 6 A). The mice were injected with IL-13 inhibitor or control protein i.p just before the second i.n. antigen challenge until $2 \mathrm{~d}$ after the third i.n. antigen challenge (Fig. $6 \mathrm{~A}$ ). The mice were rested, challenged once, and killed. The following IL-13 inhibitors were used: (a) a soluble protein consisting of the IL-13R $\alpha 2$ chain fused to an Ig heavy chain $(18,19,74,75)$ of mouse origin (IL-13R $\alpha 2-\mathrm{Fc}, 0.32-\mathrm{mg}$ dose given daily; provided by S. Goldman, Wyeth Research, Cambridge, MA), and (b) a neutralizing, polyclonal rabbit anti-mouse IL-13 antibody (0.5-1-mg dose given every other day; reference 76). Each inhibitor was tested in two independent experiments, each of which was designed with three groups of mice: (a) nonimmunized mice given i.p. and i.n. PBS, (b) mice immunized and challenged with Asp Ag and given control Ig, and (c) mice immunized and challenged with Asp Ag and given IL-13 inhibitor (Fig. 6 A). In each independent experiment, the group size was four to six mice.

i.n. challenge with recombinant IL-13. The IL-13 challenge experiments were performed in mice housed at St. Luke's Roosevelt Hospital under G. Grunig's supervision. Naive wild-type mice were given control protein (BSA, low in endotoxin; $1 \%$ in PBS; Sigma-Aldrich) or recombinant IL-13 (5 $\mu \mathrm{g}$ per dose in a $50-\mu$ l volume of PBS/BSA; PeproTech) using the schedule shown in Fig. S6 A.

Tissue recovery. At the end of each experiment, the mice were killed by an overdose of ketamine/xylazine. Blood, spleens, lung draining lymph nodes, and BALF were obtained $(18,50)$. The lungs were inflated and removed into formaldehyde. In some experiments, a single lung lobe was sutured off and removed into Hanks balanced salt solution before the inflation of the rest of the lungs with formaldehyde.

Preparation of lung sections. Formaldehyde-fixed lung tissues were embedded in paraffin, sectioned, and stained with hematoxylin and eosin (H\&E) by the Pathology Core Laboratory (Columbia University) or Schering-Plough Biopharma. From each specimen, additional sections were cut and stored at room temperature for immunohistochemical staining.

Immunohistochemistry. Sections of formaldehyde-fixed and paraffinembedded lung lobes were deparaffinized and rehydrated. Epitope retrieval was performed by boiling the sections in citrate buffer, $\mathrm{pH} 6$ (Invitrogen). Subsequent incubations were performed in a humidified chamber. Sections were reacted with hydrogen peroxide block (Lab Vision), washed, and blocked with 10\% normal donkey serum (Jackson ImmunoResearch Laboratories). The sections were then incubated with the following primary antibody pairs: biotinylated mouse anti-smooth muscle actin (clone 1A4; Lab Vision) and polyclonal rabbit anti-von Willebrand factor (Chemicon); biotinylated mouse antismooth muscle actin and monoclonal rabbit anti-Ki67 (clone SP6; Lab Vision); rabbit polyclonal anti-smooth muscle actin (Lab Vision) and biotinylated 
mouse monoclonal anti-PCNA (clone PC10; Lab Vision); with appropriate control antibodies; or with the single primary antibodies biotinylated monoclonal mouse anti-smooth muscle actin (Lab Vision), biotinylated polyclonal goat anti-RELM $\alpha$ (R\&D Systems), or rabbit polyclonal anti-RELM $\alpha$ (Abcam). The antibodies were used at concentrations recommended by the manufacturer or at $1 \mu \mathrm{g} / \mathrm{ml}$ if there were no recommendations. The following secondary reagents were used: alkaline phosphatase- or horseradish peroxidase-conjugated polyclonal donkey anti-rabbit antibody (Fab fragment, multiple absorptions; Jackson ImmunoResearch Laboratories), horseradish peroxidase-conjugated avidin (eBioscience), or alkaline phosphatase-conjugated streptavidin (Jackson ImmunoResearch Laboratories). Antibody binding was visualized using substrates for alkaline phosphatase (blue kit III, supplemented with levamisole to block the endogenous enzyme) and horseradish peroxidase (Vector NovaRed) from Vector Laboratories, producing blue (alkaline phosphatase) or red (horseradish peroxidase) reaction products. Sections stained with a single primary antibody were counterstained with Mayer's hematoxylin (Sigma-Aldrich).

Scores for pulmonary arterial remodeling and inflammation. H\&Estained sections were coded and randomized to obscure the group identity. Sections were examined with a light microscope at 200 or $400 \times$ magnification. Random, consecutive view fields were scored. 15-30 fields per lung were scored, and the mean score was calculated for each parameter.

Pulmonary arterial remodeling was scored on small- to medium-sized arteries that were located close to the airways and could be examined under the view field given with $400 \times$ magnification as follows: 1 , normal; 2 , thickened vascular wall with intact lumen and circular media (all cells follow the form given by the endothelium); and 3, lumen appears to be obstructed, and the wall is thickened and lined with disorganized layers of cells (cells in the blood vessel wall assume a pattern that differs from the lumen).

Pulmonary perivascular inflammation was scored on consecutive pulmonary blood vessels as follows: 1 , normal with very few inflammatory cells; 2 , scattered inflammatory cells up to two rings in depth; and 3, cuffs of inflammatory cells measuring three rings or more in depth.

Interstitial inflammation was scored as follows: 1 , normal; 2 , increased numbers of cells within the alveoli; and 3, consistent increase in the numbers of cells within the alveoli, appearance of multinucleated giant cells, and thickening of the alveolar septa.

System for numerical analysis of pulmonary arterial remodeling. The numeric analysis system was adapted from mathematical methods for the two-dimensional analysis of cell layers (77). Lung sections stained with H\&E were coded and randomized to obscure the group identity. 10-15 consecutive small- to medium-sized pulmonary arteries that could be examined by the view field given by $400 \times$ magnification were analyzed. Each vascular smooth muscle cell was analyzed for the type of neighboring cell (endothelial cell, smooth muscle cell, or adventitial cell) and categorized (Fig. S2) as follows: 1, the smooth muscle cell was located between an endothelial cell and the adventitia; 2 , the smooth muscle cell was located between an endothelial cell and another smooth muscle cell, or between a smooth muscle cell and the adventitia; and 3, the smooth muscle cell was located between other smooth muscle cells.

These data were used to calculate for each lung (a) the smooth muscle count (number of smooth muscle cells counted/number of arteries evaluated), (b) the percentage of layered smooth muscle cells (mean of the percentage of category 3 cells present in each of the arteries examined), and (c) the mean smooth muscle cell distribution score ([number of category 1 cells $\times 1+$ number of category 2 cells $\times 2+$ number of category 3 cells $\times 3$ ] $/$ number of arteries evaluated).

Enumeration of immunoreactive cells. All numerical determinations were performed on 10-30 pulmonary arteries viewed at $400 \times$ magnification. The group identity of the lung sections was obscured before analysis.

The mean number of proliferating cells was determined in sections stained with a proliferation marker (Ki67 or PCNA) and with an anti-smooth muscle actin antibody. Care was taken not to count proliferation marker-positive cells located within the arterial lumen or outside of the arterial wall. For each mouse, the mean number of proliferating cells (positive nuclei) per pulmonary artery was determined.

The mean number of RELM $\alpha$-positive cells that surrounded the pulmonary arteries was determined in sections stained with an anti-RELM $\alpha$ antibody and counterstained with hematoxylin. For each mouse, the mean number of RELM $\alpha$-positive cells surrounding pulmonary arteries was determined.

Photomicrographs. Photomicrographs were taken using microscopes (Nikon) equipped with the RT SPOT digital camera/software package (Diagnostic Instruments, Inc.), or with the Spot RT Color 2000 camera (model 2.2.1; Diagnostic Instruments, Inc.) and Openlab software (Improvision Inc.).

Assessment of the immune response. The evaluation of the immune response was performed as previously described (50) by determining Ig titers in the serum, enumerating $T$ cells capable of producing intracellular cytokines in cell suspensions from lung draining lymph nodes, and by determining cytokine concentrations in the BALF.

Paired antibodies and standards were purchased for mouse IgE, IgG1, and IgG2a (SouthernBiotech and BD Biosciences) to determine the concentration of total Ig in the serum using standard ELISA assays, as previously described (50).

OVA-specific IgE levels were quantitated by Luminex with a Beadlyte mouse Ig isotyping kit (Millipore). Data acquisition and analysis were performed on a Luminex 100 machine with MasterPlex software.

Intracellular cytokine staining was performed on cell suspensions prepared from the lung draining lymph nodes, as previously described (50). The cells were cultured in the presence of PMA and ionomycin for $4 \mathrm{~h}$, with the addition of Brefeldin $\mathrm{A}$ for the last $2 \mathrm{~h}$ of culture. The cells were harvested, fixed in $2 \%$ buffered formaldehyde, permeabilized, and stained with PElabeled anti-IL-5 and allophycocyanin-labeled anti-IFN- $\gamma$ mAbs (eBioscience). The cells were surface stained with FITC-labeled anti-CD8 or anti-Thy1.2 combined with PerCp-labeled anti-CD4 mAbs. The cells were examined on a FACSCalibur using CellQuest software. Electronic gates were set using the forward and side scatter profiles in combination with the surface labels to capture $\mathrm{CD}^{+} \mathrm{T}$ cells. The intracellular isotype control $\mathrm{mAbs}$ were used to set the quadrants that demarcated cytokine-positive cells.

Cytokine levels in BALF were determined using custom mouse cytokine Luminex kits (Linco) according to the manufacturer's instructions. Each BALF sample was analyzed in duplicate. Data acquisition and analysis was performed on a Luminex 100 machine with MasterPlex software.

Analysis of RVSP and right heart hypertrophy. C75BL/6 wild-type mice were primed with OVA on Alum. The animals were randomized into two groups: one was given saline aerosol, and the other was given OVA aerosol (Fig. 8). Before the measurements, the mice were color coded to obscure the type of exposure. The hemodynamic measurements were performed at Stanford University. RVSP, right ventricular function (pressure change per second), and heart rate were measured by jugular vein catheterization $(1.4 \mathrm{~F}$ catheter; Millar Instruments Inc.) connected to a pressure transducer under isoflurane anesthesia $\left(1.5-2.5 \%, 2\right.$ liter $\left.\mathrm{O}_{2} / \mathrm{min}\right)$ using a closed chest technique in unventilated mice, as previously described (78). The right ventricular hypertrophy was evaluated by Fulton index measurements (weight of right ventricle/left ventricle plus septum). Pulmonary vascular reactivity was assessed in mice anesthetized with $1.5 \%$ isoflurane, during which they were exposed to $40 \% \mathrm{O}_{2}$ (baseline) followed by $10 \% \mathrm{O}_{2}$ (hypoxia) for $10 \mathrm{~min}$ and were recovered at $40 \% \mathrm{O}_{2}$ for $10 \mathrm{~min}$.

Statistical analysis. Pairwise comparisons were performed using the twotailed Wilcoxon $U$ test for independent datasets. Analysis of data for correlation with the pulmonary arterial remodeling scores was performed using Spearman's rank correlation test. One-way analysis of variance, followed by pairwise comparisons with the Bonferroni test, was used to analyze experiments comprised of multiple groups. $\mathrm{P}<0.05$ was considered significant. 
Online supplemental material. Table S1 shows the numbers of mice and microscopic view fields analyzed for pulmonary arterial muscularization by scoring. Table S2 shows right heart function, heart rate, right heart weight, and RVSP after acute exposure to hypoxia in OVA-primed mice exposed to saline or OVA aerosols. Fig. S1 depicts proliferating cells in small- to medium-sized pulmonary arteries. Fig. S2 shows the categorization of smooth muscle cells for numerical evaluation. Fig. S3 depicts the effects of $\mathrm{CD}^{+}{ }^{+} \mathrm{T}$ cell depletion on perivascular inflammation in the lungs, and $\mathrm{T}$ cell counts in the spleens and lungs. Fig. S4 provides pulmonary arterial remodeling scores in control mice and mice primed and challenged with Asp Ag. Fig. S5 shows that pulmonary arterial remodeling scores correlate with indicators of a Th2 response. Fig. S6 depicts pulmonary arterial remodeling and interstitial inflammation in naive mice exposed to recombinant IL-13. Fig. S7 shows the correlation between pulmonary arterial remodeling scores and Th2 cells. Fig. S8 depicts RELM $\alpha$-expressing cells surrounding pulmonary arteries. Fig. S9 provides $\mathrm{T}$ cell responses and lung histology in OVA-immunized mice, given either saline or OVA aerosol, that were analyzed for hemodynamics. Online supplemental material is available at http://www.jem .org/cgi/content/full/jem.20071008/DC1.

This paper is dedicated to the memory of Jane H. Morse, M.D., professor emeritus, Columbia University.

The authors thank Samuel Goldman for the IL-13R $\alpha 2-F c$. The authors thank Michel C. Nussenzweig for his support; Patti Young, Lani Blissard, Bland Lane, and Leisa Sudderth for their inspiration; and Kesha Robinson for expert technical assistance. The work was funded in part by the Flight Attendant Medical Research Institute (G. Grunig), the American Heart Association (G. Grunig), the American Lung Association of the City of New York (G. Grunig), the Stony Wold-Herbert Fund, New York (G. Grunig), and Schering-Plough Biopharma (a subsidiary of Schering-Plough Corporation; R. de Waal Malefyt). The National Institutes of Health funded the generation of the anti-IL-13 antibody (grant HL069865 to C. Hogaboam).

Claire Emson, Jennifer Louten, and Rene de Waal Malefyt are employed by Schering-Plough Biopharma. The remainder of the authors have no conflicting financial interests.

\section{Submitted: 21 May 2007}

Accepted: 2 January 2008

\section{REFERENCES}

1. Heath, D., and J.E. Edwards. 1958. The pathology of hypertensive pulmonary vascular disease; a description of six grades of structural changes in the pulmonary arteries with special reference to congenital cardiac septal defects. Circulation. 18:533-547.

2. Wagenvoort, C.A. 1970. The pathology of primary pulmonary hypertension. J. Pathol. 101:Pi.

3. Reid, L.M. 1979. The pulmonary circulation: remodeling in growth and disease. The 1978 J. Burns Amberson lecture. Am. Rev. Respir. Dis. 119:531-546.

4. Zaiman, A., I. Fijalkowska, P.M. Hassoun, and R.M. Tuder. 2005. One hundred years of research in the pathogenesis of pulmonary hypertension. Am. J. Respir. Cell Mol. Biol. 33:425-431.

5. Jones, P.L., K.N. Cowan, and M. Rabinovitch. 1997. Tenascin-C, proliferation and subendothelial fibronectin in progressive pulmonary vascular disease. Am. J. Pathol. 150:1349-1360.

6. Simonneau, G., N. Galie, L.J. Rubin, D. Langleben, W. Seeger, G. Domenighetti, S. Gibbs, D. Lebrec, R. Speich, M. Beghetti, et al. 2004. Clinical classification of pulmonary hypertension. J. Am. Coll. Cardiol. 43:S5-S12.

7. Newman, J.H., B.L. Fanburg, S.L. Archer, D.B. Badesch, R.J. Barst, J.G. Garcia, P.N. Kao, J.A. Knowles, J.E. Loyd, M.D. McGoon, et al. 2004. Pulmonary arterial hypertension: future directions: report of a National Heart, Lung and Blood Institute/Office of Rare Diseases workshop. Circulation. 109:2947-2952.

8. Rabinovitch, M. 1992. Autoimmune disease and unexplained pulmonary hypertension. Circulation. 85:380-381.
9. Nicolls, M.R., L. Taraseviciene-Stewart, P.R. Rai, D.B. Badesch, and N.F. Voelkel. 2005. Autoimmunity and pulmonary hypertension: a perspective. Eur. Respir. J. 26:1110-1118.

10. Mouthon, L., L. Guillevin, and M. Humbert. 2005. Pulmonary arterial hypertension: an autoimmune disease? Eur. Respir. J. 26:986-988.

11. Barst, R.J., E.R. Flaster, A. Menon, M. Fotino, and J.H. Morse. 1992 Evidence for the association of unexplained pulmonary hypertension in children with the major histocompatibility complex. Circulation. 85:249-258.

12. Morse, J.H., R.J. Barst, M. Fotino, Y. Zhang, E. Flaster, A.E. Gharavi, M.J. Fritzler, M. Dominguez, and E. Angles-Cano. 1997. Primary pulmonary hypertension, tissue plasminogen activator antibodies, and HLA-DQ7. Am. J. Respir. Crit. Care Med. 155:274-278.

13. Morse, J.H., R.J. Barst, M. Fotino, Y. Zhang, E. Flaster, and M.J. Fritzler. 1996. Primary pulmonary hypertension: immunogenetic response to high-mobility group (HMG) proteins and histone. Clin. Exp. Immunol. 106:389-395.

14. Morse, J.H., R.J. Barst, and M. Fotino. 1992. Familial pulmonary hypertension: immunogenetic findings in four Caucasian kindreds. Am. Rev. Respir. Dis. 145:787-792.

15. Voehringer, D., T.A. Reese, X. Huang, K. Shinkai, and R.M. Locksley. 2006. Type 2 immunity is controlled by IL-4/IL-13 expression in hematopoietic non-eosinophil cells of the innate immune system. J. Exp. Med. 203:1435-1446.

16. Taraseviciene-Stewart, L., M.R. Nicolls, D. Kraskauskas, R. Scerbavicius, N. Burns, C. Cool, K. Wood, J.E. Parr, S.A. Boackle, and N.F. Voelkel. 2007. Absence of T cells confers increased pulmonary arterial hypertension and vascular remodeling. Am. J. Respir. Crit. Care Med. 175:1280-1289.

17. Corry, D.B., G. Grunig, H. Hadeiba, V.P. Kurup, M.L. Warnock, D. Sheppard, D.M. Rennick, and R.M. Locksley. 1998. Requirements for allergen-induced airway hyperreactivity in $\mathrm{T}$ and $\mathrm{B}$ cell-deficient mice. Mol. Med. 4:344-355.

18. Grunig, G., M. Warnock, A.E. Wakil, R. Venkayya, F. Brombacher, D.M. Rennick, D. Sheppard, M. Mohrs, D.D. Donaldson, R.M. Locksley, and D.B. Corry. 1998. Requirement for IL-13 independently of IL-4 in experimental asthma. Science. 282:2261-2263.

19. Donaldson, D.D., M.J. Whitters, L.J. Fitz, T.Y. Neben, H. Finnerty, S.L. Henderson, R.M. O'Hara Jr., D.R. Beier, K.J. Turner, C.R. Wood, and M. Collins. 1998. The murine IL-13 receptor alpha 2: molecular cloning, characterization, and comparison with murine IL-13 receptor alpha 1. J. Immunol. 161:2317-2324.

20. Wills-Karp, M. 2004. Interleukin-13 in asthma pathogenesis. Immunol. Rev. 202:175-190.

21. Elias, J.A., M.J. Kang, K. Crouthers, R. Homer, and C.G. Lee. 2006. State of the art. Mechanistic heterogeneity in chronic obstructive pulmonary disease: insights from transgenic mice. Proc. Am. Thorac. Soc. 3:494-498.

22. Frid, M.G., J.A. Brunetti, D.L. Burke, T.C. Carpenter, N.J. Davie, J.T. Reeves, M.T. Roedersheimer, N. van Rooijen, and K.R. Stenmark. 2006. Hypoxia-induced pulmonary vascular remodeling requires recruitment of circulating mesenchymal precursors of a monocyte $/ \mathrm{mac}-$ rophage lineage. Am. J. Pathol. 168:659-669.

23. Stutz, A.M., L.A. Pickart, A. Trifilieff, T. Baumruker, E. PrieschlStrassmayr, and M. Woisetschlager. 2003. The Th2 cell cytokines IL-4 and IL-13 regulate found in inflammatory zone 1/resistin-like molecule alpha gene expression by a STAT6 and CCAAT/enhancer-binding protein-dependent mechanism. J. Immunol. 170:1789-1796.

24. Liu, T., H. Jin, M. Ullenbruch, B. Hu, N. Hashimoto, B. Moore, A. McKenzie, N.W. Lukacs, and S.H. Phan. 2004. Regulation of found in inflammatory zone 1 expression in bleomycin-induced lung fibrosis: role of IL-4/IL-13 and mediation via STAT-6. J. Immunol. 173:3425-3431.

25. Teng, X., D. Li, H.C. Champion, and R.A. Johns. 2003. FIZZ1/ RELMalpha, a novel hypoxia-induced mitogenic factor in lung with vasoconstrictive and angiogenic properties. Circ. Res. 92:1065-1067.

26. Rabinovitch, M., N. Chesler, and R.C. Molthen. 2007. Point: Counterpoint: Chronic hypoxia-induced pulmonary hypertension does/does not lead to loss of pulmonary vasculature. J. Appl. Physiol. 103:1449-1451. 
27. Voelkel, N.F., and C.D. Cool. 2003. Pulmonary vascular involvement in chronic obstructive pulmonary disease. Eur. Respir. J. Suppl. 46:28s-32s.

28. Hoeper, M.M., and L.J. Rubin. 2006. Update in pulmonary hypertension 2005. Am. J. Respir. Crit. Care Med. 173:499-505.

29. Tuder, R.M., C.D. Cool, C. Jennings, and N.F. Voelkel. 1998. Pulmonary vascular involvement in interstitial lung disease. In Interstitial Lung Disease. M.I. Schwarz and T.E. King, editors. BC Decker Publishing, Toronto. 251-263.

30. Petitpretz, P., F. Brenot, R. Azarian, F. Parent, B. Rain, P. Herve, and G. Simonneau. 1994. Pulmonary hypertension in patients with human immunodeficiency virus infection. Comparison with primary pulmonary hypertension. Circulation. 89:2722-2727.

31. Opravil, M., M. Pechere, R. Speich, H.I. Joller-Jemelka, R. Jenni, E.W. Russi, B. Hirschel, and R. Luthy. 1997. HIV-associated primary pulmonary hypertension. A case control study. Swiss HIV Cohort Study. Am. J. Respir. Crit. Care Med. 155:990-995.

32. Dorfmuller, P., F. Perros, K. Balabanian, and M. Humbert. 2003 Inflammation in pulmonary arterial hypertension. Eur. Respir. J. 22:358-363.

33. Ito, T., T. Okada, H. Miyashita, T. Nomoto, M. Nonaka-Sarukawa, R. Uchibori, Y. Maeda, M. Urabe, H. Mizukami, A. Kume, et al. 2007. Interleukin-10 expression mediated by an adeno-associated virus vector prevents monocrotaline-induced pulmonary arterial hypertension in rats. Circ. Res. 101:734-741.

34. Greenway, S., R.J. van Suylen, G. Du Marchie Sarvaas, E. Kwan, N. Ambartsumian, E. Lukanidin, and M. Rabinovitch. 2004. S100A4/ Mts1 produces murine pulmonary artery changes resembling plexogenic arteriopathy and is increased in human plexogenic arteriopathy. Am. J. Pathol. 164:253-262.

35. Said, S.I., S.A. Hamidi, K.G. Dickman, A.M. Szema, S. Lyubsky, R.Z. Lin, Y.P. Jiang, J.J. Chen, J.A. Waschek, and S. Kort. 2007. Moderate pulmonary arterial hypertension in male mice lacking the vasoactive intestinal peptide gene. Circulation. 115:1260-1268.

36. Rich, S., K. Kieras, K. Hart, B.M. Groves, J.D. Stobo, and B.H. Brundage. 1986. Antinuclear antibodies in primary pulmonary hypertension. J. Am. Coll. Cardiol. 8:1307-1311.

37. Isern, R.A., M. Yaneva, E. Weiner, A. Parke, N. Rothfield, D. Dantzker, S. Rich, and F.C. Arnett. 1992. Autoantibodies in patients with primary pulmonary hypertension: association with anti-Ku. Am. J. Med. 93:307-312.

38. Langevitz, P., D. Buskila, D.D. Gladman, G.A. Darlington, V.T. Farewell, and P. Lee. 1992. HLA alleles in systemic sclerosis: association with pulmonary hypertension and outcome. Br. J. Rheumatol. 31:609-613.

39. Morse, J.H., S. Antohi, K. Kasturi, S. Saito, M. Fotino, M. Humbert, G. Simonneau, R.J. Basst, and C.A. Bona. 2000. Fine specificity of antifibrillin-1 autoantibodies in primary pulmonary hypertension syndrome. Scand. J. Immunol. 51:607-611.

40. Caslin, A.W., D. Heath, B. Madden, M. Yacoub, J.R. Gosney, and P. Smith. 1990. The histopathology of 36 cases of plexogenic pulmonary arteriopathy. Histopathology. 16:9-19.

41. Heath, D., and M. Yacoub. 1991. Lung mast cells in plexogenic pulmonary arteriopathy. J. Clin. Pathol. 44:1003-1006.

42. Tuder, R.M., B. Groves, D.B. Badesch, and N.F. Voelkel. 1994. Exuberant endothelial cell growth and elements of inflammation are present in plexiform lesions of pulmonary hypertension. Am. J. Pathol. 144:275-285.

43. Perros, F., P. Dorfmuller, R. Souza, I. Durand-Gasselin, S. Mussot, M. Mazmanian, P. Herve, D. Emilie, G. Simonneau, and M. Humbert. 2007. Dendritic cell recruitment in lesions of human and experimental pulmonary hypertension. Eur. Respir. J. 29:462-468.

44. Humbert, M., G. Monti, F. Brenot, O. Sitbon, A. Portier, L. GrangeotKeros, P. Duroux, P. Galanaud, G. Simonneau, and D. Emilie. 1995. Increased interleukin-1 and interleukin-6 serum concentrations in severe primary pulmonary hypertension. Am. J. Respir. Crit. Care Med. 151:1628-1631.

45. Balabanian, K., A. Foussat, P. Dorfmuller, I. Durand-Gasselin, F. Capel, L. Bouchet-Delbos, A. Portier, A. Marfaing-Koka, R. Krzysiek, A.C. Rimaniol, et al. 2002. CX(3)C chemokine fractalkine in pulmonary arterial hypertension. Am. J. Respir. Crit. Care Med. 165:1419-1425.
46. Curtis, J.L., M.L. Warnock, S.M. Arraj, and H.B. Kaltreider. 1990. Histologic analysis of an immune response in the lung parenchyma of mice. Angiopathy accompanies inflammatory cell influx. Am. J. Pathol. 137:689-699.

47. Tormanen, K.R., L. Uller, C.G. Persson, and J.S. Erjefalt. 2005. Allergen exposure of mouse airways evokes remodeling of both bronchi and large pulmonary vessels. Am. J. Respir. Crit. Care Med. 171:19-25.

48. Witzenrath, M., B. Ahrens, S.M. Kube, A.C. Hocke, S. Rosseau, E. Hamelmann, N. Suttorp, and H. Schutte. 2006. Allergic lung inflammation induces pulmonary vascular hyperresponsiveness. Eur. Respir. J. 28:370-377.

49. Asosingh, K., S. Swaidani, M. Aronica, and S.C. Erzurum. 2007. Th1and Th2-dependent endothelial progenitor cell recruitment and angiogenic switch in asthma. J. Immunol. 178:6482-6494.

50. Grunig, G., D.B. Corry, M.W. Leach, B.W. Seymour, V.P. Kurup, and D.M. Rennick. 1997. Interleukin-10 is a natural suppressor of cytokine production and inflammation in a murine model of allergic bronchopulmonary aspergillosis. J. Exp. Med. 185:1089-1099.

51. Ford, J.G., D. Rennick, D.D. Donaldson, R. Venkayya, C. McArthur, E. Hansell, V.P. Kurup, M. Warnock, and G. Grunig. 2001. IL-13 and IFN-gamma: interactions in lung inflammation. J. Immunol. 167: 1769-1777.

52. Vargaftig, B.B., and M. Singer. 2003. Leukotrienes mediate murine bronchopulmonary hyperreactivity, inflammation, and part of mucosal metaplasia and tissue injury induced by recombinant murine interleukin-13 Am. J. Respir. Cell Mol. Biol. 28:410-419.

53. Zhu, Z., R.J. Homer, Z. Wang, Q. Chen, G.P. Geba, J. Wang, Y. Zhang, and J.A. Elias. 1999. Pulmonary expression of interleukin-13 causes inflammation, mucus hypersecretion, subepithelial fibrosis, physiologic abnormalities, and eotaxin production. J. Clin. Invest. 103:779-788.

54. Zhu, Z., T. Zheng, R.J. Homer, Y.K. Kim, N.Y. Chen, L. Cohn, Q. Hamid, and J.A. Elias. 2004. Acidic mammalian chitinase in asthmatic Th2 inflammation and IL-13 pathway activation. Science. 304:1678-1682.

55. Ma, B., M.R. Blackburn, C.G. Lee, R.J. Homer, W. Liu, R.A. Flavell, L. Boyden, R.P. Lifton, C.X. Sun, H.W. Young, and J.A. Elias. 2006. Adenosine metabolism and murine strain-specific IL-4-induced inflammation, emphysema, and fibrosis. J. Clin. Invest. 116:1274-1283.

56. Hoshikawa, Y., P. Nana-Sinkam, M.D. Moore, S. Sotto-Santiago, T. Phang, R.L. Keith, K.G. Morris, T. Kondo, R.M. Tuder, N.F. Voelkel, and M.W. Geraci. 2003. Hypoxia induces different genes in the lungs of rats compared with mice. Physiol. Genomics. 12:209-219.

57. Renigunta, A., C. Hild, F. Rose, W. Klepetko, F. Grimminger, W Seeger, and J. Hanze. 2006. Human RELMbeta is a mitogenic factor in lung cells and induced in hypoxia. FEBS Lett. 580:900-903.

58. Rabinovitch, M. 2005. Cellular and molecular pathobiology of pulmonary hypertension conference summary. Chest. 128:642S-646S.

59. West, J., K. Fagan, W. Steudel, B. Fouty, K. Lane, J. Harral, M. HoedtMiller, Y. Tada, J. Ozimek, R. Tuder, and D.M. Rodman. 2004. Pulmonary hypertension in transgenic mice expressing a dominant-negative BMPRII gene in smooth muscle. Circ. Res. 94:1109-1114.

60. Merklinger, S.L., R.A. Wagner, E. Spiekerkoetter, A. Hinek, R.H Knutsen, M.G. Kabir, K. Desai, S. Hacker, L. Wang, G.M. Cann, et al. 2005. Increased fibulin-5 and elastin in S100A4/Mts1 mice with pulmonary hypertension. Circ. Res. 97:596-604.

61. Crossno, J.T., Jr., C.V. Garat, J.E. Reusch, K.G. Morris, E.C. Dempsey, I.F. McMurtry, K.R. Stenmark, and D.J. Klemm. 2007. Rosiglitazone attenuates hypoxia-induced pulmonary arterial remodeling. Am. J. Physiol. Lung Cell. Mol. Physiol. 292:L885-L897.

62. Fried, R., G. Falkovsky, J. Newburger, A.I. Gorchakova, M Rabinovitch, M.I. Gordonova, D. Fyler, L. Reid, and V. Burakovsky. 1986. Pulmonary arterial changes in patients with ventricular septal defects and severe pulmonary hypertension. Pediatr. Cardiol. 7:147-154

63. Rabinovitch, M., J.F. Keane, W.I. Norwood, A.R. Castaneda, and L. Reid. 1984. Vascular structure in lung tissue obtained at biopsy correlated with pulmonary hemodynamic findings after repair of congenital heart defects. Circulation. 69:655-667.

64. Bethlem, E.P., P. Schettino Gde, and C.R. Carvalho. 1997. Pulmonary schistosomiasis. Curr. Opin. Pulm. Med. 3:361-365. 
65. de Cleva, R., P. Herman, V. Pugliese, B. Zilberstein, W.A. Saad, J.J. Rodrigues, and A.A. Laudanna. 2003. Prevalence of pulmonary hypertension in patients with hepatosplenic Mansonic schistosomiasis-prospective study. Hepatogastroenterology. 50:2028-2030.

66. Barbosa, M.M., J.A. Lamounier, E.C. Oliveira, M.V. Souza, D.S. Marques, A.A. Silva, and J.R. Lambertucci. 1996. Pulmonary hypertension in schistosomiasis mansoni. Trans. R. Soc. Trop. Med. Hyg. 90 663-665.

67. Nelson, C.T., J.W. McCall, S.B. Rubin, L.F. Buzhardt, D.W. Dorion, W. Graham, S.L. Longhofer, J. Guerrero, C. Robertson-Plouch, and A. Paul; Executive Board of the American Heartworm Society. 2005 Guidelines for the diagnosis, prevention and management of heartworm (Dirofilaria immitis) infection in cats. Vet. Parasitol. 133:267-275.

68. Nelson, C.T., J.W. McCall, S.B. Rubin, L.F. Buzhardt, D.W. Dorion, W. Graham, S.L. Longhofer, J. Guerrero, C. Robertson-Plouch, and A. Paul; Executive Board of the American Heartworm Society. 2005. Guidelines for the diagnosis, prevention and management of heartworm (Dirofilaria immitis) infection in dogs. Vet. Parasitol. 133:255-266.

69. Rawlings, C.A., R.L. Farrell, and R.M. Mahood. 1990. Morphologic changes in the lungs of cats experimentally infected with Dirofilaria immitis. Response to aspirin. J. Vet. Intern. Med. 4:292-300.

70. Sasaki, Y., H. Kitagawa, and Y. Hirano. 1992. Relationship between pulmonary arterial pressure and lesions in the pulmonary arteries and parenchyma, and cardiac valves in canine dirofilariasis. J. Vet. Med. Sci. $54: 739-744$
71. Kopf, M., G. Le Gros, M. Bachmann, M.C. Lamers, H. Bluethmann, and G. Kohler. 1993. Disruption of the murine IL-4 gene blocks Th2 cytokine responses. Nature. 362:245-248.

72. Kurup, V.P., H. Choi, A. Resnick, J. Kalbfleisch, and J.N. Fink. 1990. Immunopathological response of $\mathrm{C} 57 \mathrm{BL} / 6$ and $\mathrm{C} 3 \mathrm{H} / \mathrm{HeN}$ mice to Aspergillus fumigatus antigens. Int. Arch. Allergy Appl. Immunol. 91:145-154.

73. Arora, S., R.A. McDonald, G.B. Toews, and G.B. Huffnagle. 2006. Effect of a CD4-depleting antibody on the development of Cryptococcus neoformans-induced allergic bronchopulmonary mycosis in mice. Infect. Immun. 74:4339-4348.

74. Wills-Karp, M., J. Luyimbazi, X. Xu, B. Schofield, T.Y. Neben, C.L. Karp, and D.D. Donaldson. 1998. Interleukin-13: central mediator of allergic asthma. Science. 282:2258-2261.

75. Taube, C., C. Duez, Z.H. Cui, K. Takeda, Y.H. Rha, J.W. Park, A. Balhorn, D.D. Donaldson, A. Dakhama, and E.W. Gelfand. 2002 The role of IL-13 in established allergic airway disease. J. Immunol. 169:6482-6489.

76. Blease, K., C. Jakubzick, J. Westwick, N. Lukacs, S.L. Kunkel, and C.M. Hogaboam. 2001. Therapeutic effect of IL-13 immunoneutralization during chronic experimental fungal asthma. J. Immunol. 166:5219-5224.

77. Zallen, J.A., and R. Zallen. 2004. Cell-pattern disordering during convergent extension in Drosophila. J. Phys. Condens. Matter. 16:S5073-S5080.

78. Zaidi, S.H., X.M. You, S. Ciura, M. Husain, and M. Rabinovitch. 2002. Overexpression of the serine elastase inhibitor elafin protects transgenic mice from hypoxic pulmonary hypertension. Circulation. 105:516-521. 